UDC 74/77.041.5:929 Gorkij M. https://doi.org/10.18485/ms_zmss.2020.97.5

\title{
Елена Гордеева
}

Нижегородский государственный университет им. Н И. Лобачевского elgord1@yandex.ru

\section{Елена Сонина}

Санкт-Петербургский государственный университет sonina@mail.ru

\section{Elena Gordeeva}

National Research Lobachevsky State University of Nizhni Novgorod elgord1@yandex.ru

\section{Elena Sonina}

St Petersburg State University

sonina@mail.ru

\section{МАКСИМ ГОРЬКИЙ И ЕГО ЛИТЕРАТУРНОЕ ОКРУЖЕНИЕ: СТРАНИЦЫ ИКОНОГРАФИИ}

\section{MAXIM GORKY AND HIS LITERARY ENVIRONMENT: PAGES OF ICONOGRAPHY}

В работе систематизирована та часть иконографии М. Горького (фотопортреты, картины, карикатуры), где известный писатель представлен на фоне литературного окружения. Исследование, основанное на интерпретации визуальных образов, помогает уточнить взаимоотношения Горького как с маститыми российскими и зарубежными писателями, так и с начинающими авторами.

Ключевые слова: Максим Горький, иконография, литературное окружение.

In this work, that part of the iconography of Maxim Gorky (photo, paintings, caricatures), where the famous writer is presented on the background of the literary environment, is systematized. The study, based on the interpretation of visual images, helps to clarify Gorky's relationship with venerable Russian and foreign writers, as well as with beginning authors.

Key words: Maxim Gorky, iconography, literary environment.

Памяти Тани Попович

Современные российские музеи, и прежде всего музей А. М. Горького в Москве, располагают уникальными коллекциями фотодокументов, картин, карикатур, представляющими иконографию писателя. В этих 
произведениях отражен не только чрезвычайно широкий круг лиц, с которыми Горький взаимодействовал (политики, общественные деятели, ученые, актеры и певцы, писатели и журналисты); в них запечатлена эпоха, в которую он жил, а также характер его взаимоотношений с этими известными людьми. Охватить всю иконографию писателя в рамках одной статьи невозможно. Поскольку сам Горький был, прежде всего, писателем и журналистом, важно исследовать ту часть иконографии, которая помогает уточнить отдельные страницы его творческой биографии в контексте развития отечественной и зарубежных литератур. В рамках настоящего исследования систематизирована фотографическая и живописная горьковская иконография, представляющая писателя в литературном окружении, дореволюционного и советского периодов, а также рассмотрен дореволюционный период карикатурной части его иконографии той же тематической направленности.

\section{Горький в фотографиях и живописи}

Фотолетопись жизни Горького, включающая портреты с 1880-х гг. вплоть до последних дней жизни, свидетельствует о том, что снимали писателя, как правило, мастера художественной фотографии. Одним из них был земляк Горького, Максим Петрович Дмитриев, создатель российской школы фоторепортажа. За период жизни писателя в Нижнем Новгороде (до 1904 г.) Дмитриев сделал более 100 горьковских фотографий, как портретов, так и групповых снимков. Авторы одного из последних исследований, связанных с иконографией Горького, Р. А. Гоголев, Я. И. Гройсман, П. А. Аксенова указывают: «Несмотря на то, что в Нижнем Новгороде работало много фотографов — профессионалов, Горький, в отличие от жены, благоволившей к Карелину, предпочитал фотографироваться именно у Дмитриева: может быть, дружеские отношения имели значение (Пешковы и Дмитриевы дружили семьями), а, может быть, резкий почерк человека нового времени более привлекал молодого писателя» (Максим Горький и Нижний Новгород 2017: 140).

Горький постоянно обращался к Дмитриеву с заказами, направлял в ателье к фотохудожнику своих гостей (Л. Андреева, С. Скитальца, И. Бунина, Ф. Шаляпина и др.), «советовал переснимать фотографии писателей, делать монтажи и распространять их» (Современники А. М. Горького 2002: 53). Именно таким образом появилась фотография, на которой представлены Л. Толстой, Чехов и Горький (Гаспра, 1901). На открытой к 150-летию писателя в Литературном музее Нижнего Новгорода выставке «Новая жизнь». Максим Горький и первая русская революция» объяснен секрет этой мистификации. 14 ноября 1901 г. М. Горький посетил Л. Толстого в Гаспре. Там С. А. Толстая и подарила нижегородскому писателю сделанный ею снимок Чехова и Толстого, сидящих на веранде. 
В начале 1902 г. Горький переслал фотографию Дмитриеву и просил переснять известных писателей отдельно и вместе, чтобы потом можно было продавать получившиеся снимки. Фотограф, в свою очередь, решил сделать земляку сюрприз: взял негатив и, перевернув его обратной стороной, искусно впечатал между Чеховым и Толстым один из лучших портретов Горького. Снимок пришелся по вкусу аудитории и до сих пор украшает многие авторитетные исследования, однако без упоминания того обстоятельства, что это фотомонтаж. По-видимому, вдохновленный именно этой работой Дмитриева, А. С. Аксельрод в 1946 г. написал картину «А. М. Горький, А. П. Чехов и Л. Н. Толстой» (А. М. Горький в изобразительном искусстве 1969: 122).

Значительное место в фотолетописи Горького занимают не только профессиональные, но и любительские фотографии. Широко растиражированный в России и за рубежом снимок, сделанный в Ясной Поляне 8 октября 1900 г. С. А. Толстой и переснятый Дмитриевым, яркое тому свидетельство. О встрече с литературным мэтром, запечатленной на этой фотографии, Горький вспоминал в литературном очерке «Лев Толстой»: «Второй раз я видел его в Ясной. Был осенний хмурый день, моросил дождь, а он, надев тяжелое драповое пальто и высокие кожаные ботинки - настоящие мокроступы, - повел меня гулять в березовую рощу. Молодо прыгает через канавы, лужи, отряхает капли дождя с веток на голову себе и превосходно рассказывает, как Шеншин объяснил Шопенгауэра в этой роще. И ласково рукою любовно гладит сыроватые атласные стволы берез» (Горький М. Лев Толстой 2014: 363).

Более рельефно встречи Горького и Толстого отражены в изобразительном искусстве. Вообще из всех русских писателей XX в. Горький выделялся своими постоянными связями с художниками. Его друзьями были И. Репин, В. Васнецов, В. Серов, М. Нестеров, И. Гинцбург, И. Бродский, П. Корин, В. Ходасевич, В. Яковлев, Кукрыниксы, В. Богородский и многие другие (Горький и художники 1964: 5). Этот факт в биографии писателя, безусловно, обогатил его иконографию. В частности описанная выше встреча двух писателей нашла отражение в картине В. А. Успенского и Н. А. Павлова «Л. Н. Толстой и А. М. Горький в Ясной Поляне» (1939), где собеседники, стоят, обратившись друг к другу, в липовой аллее Яснополянского парка (А. М. Горький в изобразительном искусстве 1969: 119). Хотя большинство картин, представляющих Горького в его литературном окружении, относится к посмертной иконографии писателя, нам удалось выявить одну прижизненную картину «Рыбная ловля» (1903), написанную Н. Н. Буниным. На ней изображены Л. Толстой, Л. Андреев и М. Горький, а также крестьянин и мальчик на берегу реки, у невода (Горький и художники 1964: 313).

Примечательно, что желание Толстого познакомиться с начинающим писателем Горьким передал последнему А. П. Чехов. Среди любительских фотографий в иконографии Горького особое место занимают те, что 
сделаны Средиными - Леонидом Валентиновичем, ялтинским врачом, другом писателя, и его сыном Алексеем. Им принадлежат почти все крымские снимки Горького с 1899 по 1903 гг. (Современники А. М. Горького 2002: 12), в том числе групповые снимки Горького и Чехова. Личная встреча двух писателей, положившая начало дружеским отношениям, состоялась в Ялте 19 марта 1899 г. Многие их последующие встречи происходили там же, правда, в мае 1901 г. Чехов вместе с О. Л. Книппер посетил Горького в Нижнем Новгороде. Благодаря Горькому и его окружению на рубеже XIX-XX вв. Нижний Новгород становится одним из самых притягательных городов для литературной элиты России. Сюда, в гости к Горькому, кроме Чехова, приезжали Леонид Андреев, Иван Бунин, Скиталец (С. Г. Петров), Федор Шаляпин и другие знаменитости (Максим Горький и Нижний Новгород 2012: 12).

Однако со многими из перечисленных современников Горький снимался не только в Нижнем Новгороде, но и в Москве. В конце 1902 г., в фотоателье К. А. Фишера, был выполнен один из самых популярных в России снимков, растиражированный не только в печатных изданиях, но выпущенный и в виде почтовых открыток. На нем была запечатлена группа из семи человек: Горький, Скиталец, Бунин, Андреев, Телешов, Чириков и Шаляпин (рuс. 1). Существовало несколько вариантов этого снимка, на котором изображены участники литературного объединения «Среда», возглавляемого Н. Д. Телешовым (Лебедева 1992: 12). Приезжая в Москву, Горький посещал заседания «Среды». На этом групповом снимке среди прочих изображен и Скиталец, писатель, поэт, музыкант, близкий друг Горького. Отец Скитальца был столяром, увлекавшимся игрой на гуслях. Сын перенял это искусство от отца и часто играл своим друзьям, в том числе Горькому. Сохранились фотографии, на которых изображены Горький и Скиталец с гуслями (Максим Горький и Нижний Новгород 2017: 111). Интересно, что в фотолетописи Горького много постановочных снимков, которые отражают веселые сценки, указывают на открытость друзей шуткам и театральным эффектам. Сохранились снимки, выполненные в 1903 г. Я. О. Берсоном на даче П. П. Малиновского. На них, в частности, изображено, как Горький и Шаляпин режут ножом и вилкой писателя Чирикова, при этом все трое сидят на дереве (Максим Горький и Нижний Новгород 2017: 113). Первая совместная фотография Горького и Е. Чирикова выполнена в редакции журнала «Жизнь». Многие их совместные фотографии, сделанные в Москве, Нижнем Новгороде, Крыму, относятся к 1903 г.

Примечательно, что и со Скитальцем, и с Чириковым Горький познакомился в Самаре, где в 1895-1896 гг. работал в редакции Самарской газетьл. Этот факт в биографии писателя также нашел отражение в фотографиях (А. М. Горький в портретах, иллюстрациях, документах 1962: 48). Из Нижнего Новгорода в Самару Горький уехал по настоянию В. Г. Короленко. Удивляет отсутствие снимков Горького со своим земляком. 


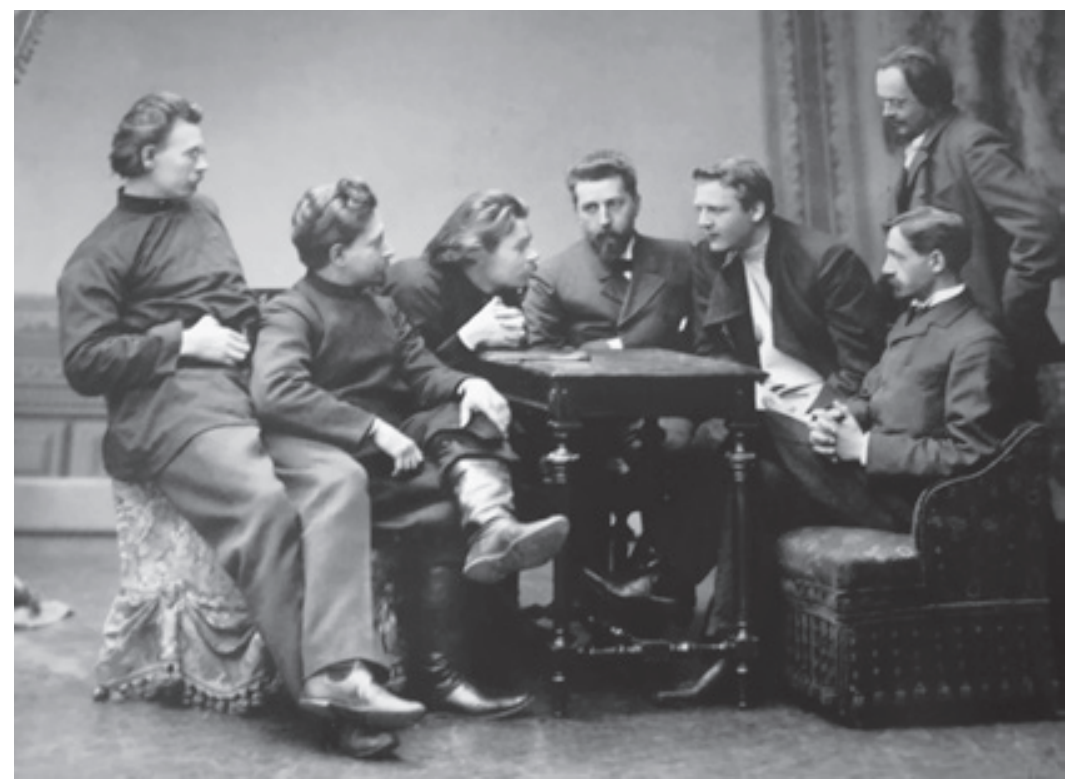

Рис. 1. М. Горький и члены литературной группь «Среда». Фото К. А. Фишера (1902)

Видимо, это объясняется нелюбовью Короленко ходить к фотографам. Единственное доказательство серьезного творческого взаимодействия двух нижегородцев, которое нам удалось найти в горьковской иконографии, и то посмертной, это картина В. И. Авериной «А. М. Горький и В. Г. Короленко в Нижнем Новгороде» (1946) (А. М. Горький в изобразительном искусстве 1969: 121). На ней писатели беседуют, сидя на скамье под деревом на Откосе. Перед ними открывается вид на одно из самых красивых мест Нижнего Новгорода, где происходит слияние Оки и Волги.

Писатель неоднократно называл Короленко своим учителем. Однако в письме к Т. Н. Галапуре 2 декабря 1916 г. Короленко писал: «Многие считают, что благодаря моему покровительству Горький стал писателем. Это басня. Он стал писателем благодаря большому таланту. Я только прочитывал (да и то не все) его первые рассказы и откровенно говорил свое мнение» (А. М. Горький и В. Г. Короленко: 1957: 220).

Свое подчас критическое мнение о раннем творчестве Горького высказывал и Н. Г. Гарин-Михайловский, печатавший в Самарской газете свои небольшие рассказы. Именно последний сказал Горькому: «Это вы - Горький, да? Недурно пишете. А как Хламида — плохо. Это ведь тоже вы, Хламида? <...> Фельетонист вы слабый. Фельетонист должен быть немножко сатириком, - а у вас этого нет» (Горький М. О ГаринеМихайловском 2014: 472).

Примечательно, что на картине И. Е. Репина «А. М. Горький читает в Пенатах свою пьесу “Дети солнца”》 (1905) (рис. 2) среди слушателей 


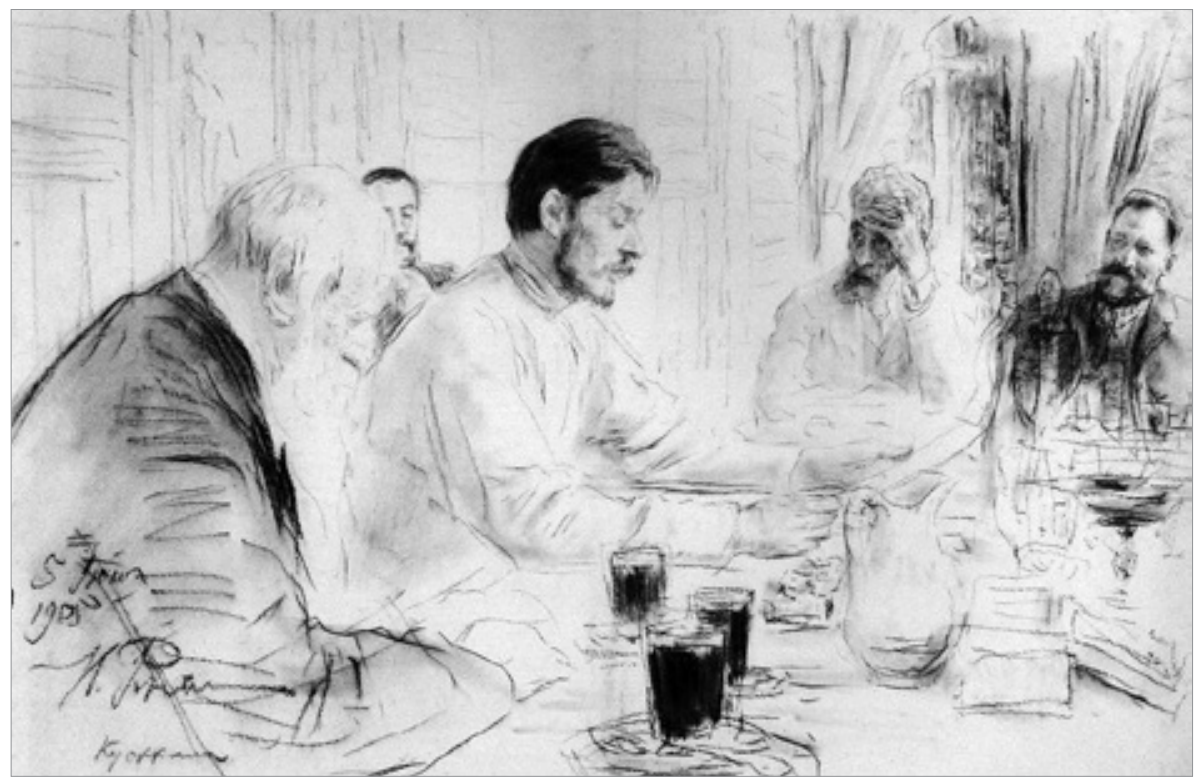

Рис. 2. И. Е. Репин. А. М. Горький читает в Пенатах свою пьесу «Дети солниа» (1905)

писателя изображен и Гарин-Михайловский (Горький и художники 1964: 329).

Отдельной страницей в иконографии Горького являются фотоснимки и картины, связанные с его заграничными поездками и жизнью за пределами России. Так, например, о большом интересе к писателю мировых знаменитостей свидетельствуют многочисленные фотографии, выполненные крупными американскими мастерами Алисой Бутон и Джорждем Бэйном во время полугодового пребывания Горького в 1906 г. в США (А. М. Горький и его современники 1997: 11). 29 марта 1906 г. в честь Горького в нью-йоркском литературном клубе «А» состоялся обед, на котором присутствовали члены Комитета содействия делу русской революции, в том числе и Марк Твен (Никитин 2017: 152). Встреча двух писателей запечатлена в фотолетописи Горького. Вечером того же дня, когда русский писатель познакомился с Марком Твеном, он присутствовал и на приеме, устроенным издателем журнала Wilchire Magazine Генри Гейлордом Уилшайром. Здесь Горький впервые встретил Герберта Уэллса, незадолго до этого приехавшего в Соединенные Штаты. Спустя год русский и английский писатели встретились в Лондоне, после чего плотно общались еще дважды - в 1920 и 1934 гг., когда Уэллс приезжал в Россию. Прибыв в нашу страну в 1920 г., Уэллс останавливался, как он писал впоследствии, «у своего старого друга Максима Горького» (Архив A. М. Горького 1960: 75). Этот факт творческого и человеческого общения двух художников подробно запечатлен на фотографиях. Примечательно, 


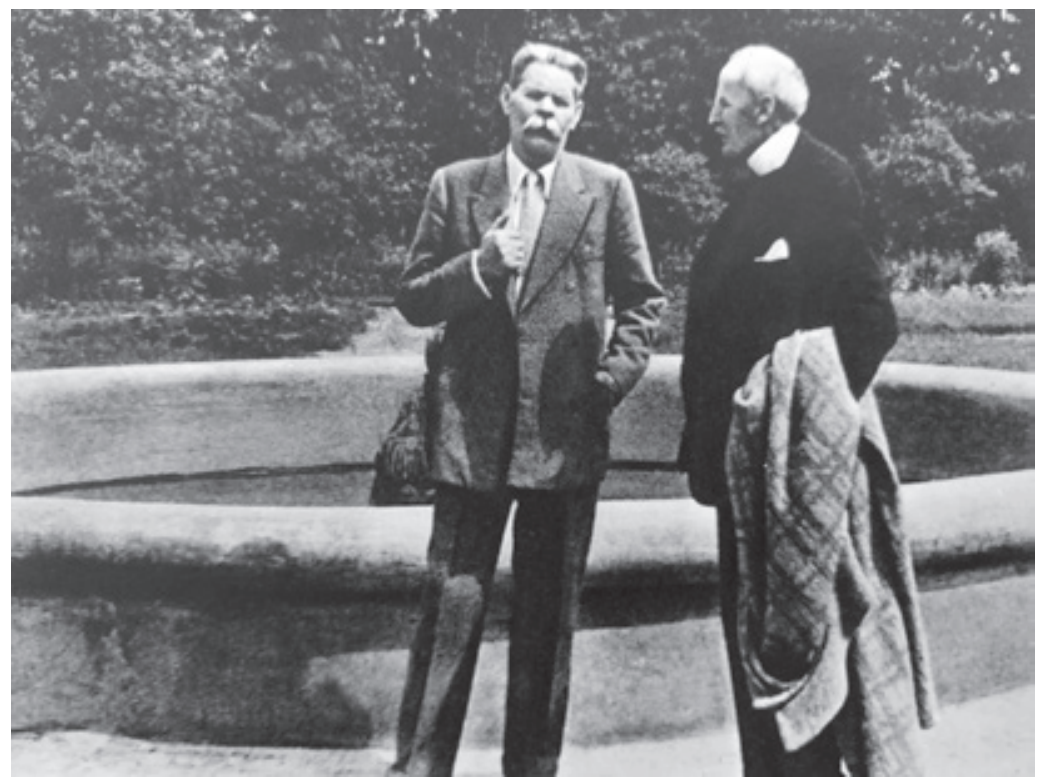

Puc. 3. А. М. Горький и Р. Роллан (1935)

что Горький в этот период был председателем Петроградской комиссии по улучшению быта ученых, под эгидой которой в городе начал работать клуб научной интеллигенции (Дом ученых). Осенью 1920 г. по приглашению Горького клуб посетил Уэллс. Английский писатель в значительной степени способствовал комплектованию Читальни клуба заграничными изданиями, что подтверждается перепиской Горького с Уэллсом (Архив А. М. Горького 1960: 68-71).

В архиве А. М. Горького имеется более 400 адресованных ему писем иностранных писателей, из которых около 100 принадлежат Ромену Роллану. В эпистолярном наследии самого Горького насчитывается свыше 200 писем, написанных им зарубежным литераторам, и около половины из них - Роллану. Переписка писателей длилась примерно 20 лет, однако их личное знакомство произошло лишь в 1935 г., когда французский художник приехал в Советский Союз и жил у Горького. Еще в 1917 г. Роллан вспоминал: «Пятнадцать лет назад, в Париже, в помещении маленькой лавчонки, в нижнем этаже одного из домов на улице Сорбонны, где мы собирались, - Шарль Пеги, я и еще несколько человек, только что основавших "Cahiers de la Quinzaine”, - одна только фотография украшала наш редакционный кабинет, бедный, чистый, аккуратно прибранный, уставленный книжными полками. Это фотография изображала Толстого и Горького, стоящих рядом в саду Ясной Поляны» (Роллан 1935: 127-128). Целая коллекция снимков самого Роллана с Горьким, сделанных в 1935 г., во время пребывания французского писателя в гостях у своего 
русского корреспондента в Горках, помогает изучать творческое взаимодействие двух литераторов ( писателей нашел отражение и в живописи, о чем свидетельствует эскиз П. Д. Корина «А. М. Горький, И. В. Сталин и Ромен Роллан» (1939), изображающий группу перечисленных деятелей на веранде дачи Горького в Горках (А. М. Горький в изобразительном искусстве 1969: 39).

Горький был не только писателем. Значительная доля его творческих усилий была направлена на журналистскую, издательскую и редакторскую деятельность. Именно поэтому в иконографии писателя эта сторона деятельности представлена многочисленными групповыми фотографиями (например, изображающими Горького во Всероссийском союзе писателей в Доме Герцена в 1928 г., в окружении В. Катаева, Л. Леонова, В. Лидина и др., писателей национальных республик в гостях у А. М. Горького в Горках в 1934 г.; но главным образом, передающими общение художника с различными группами литераторов и отдельными авторами, в том числе А. Н. Толстым, М. Е. Кольцовым и др., на I Всесоюзном съезде советских писателей в 1934 г.) (А. М. Горький в портретах, иллюстрациях, документах 1962: 356, 400, 405, 408, 412). Теме общения Горького с советскими журналистами и литераторами (общения, как показали исследования постсоветского периода, зачастую непростого, противоречивого, порой мешающего развитию молодых авторов) посвящены и носящие фотографический характер художественные полотна: Бродского И. И. «А. М. Горький среди рабкоров» (1929), Кроткова В. А. «Выступление А. М. Горького на собрании рабкоров в Тифлисе», Бруни Л. А. «А. М. Горький на 1-м Всесоюзном съезде советских писателей» (1934), Дудника С. И. с аналогичным названием (1934) (A. М. Горький в изобразительном искусстве 1969: 36-37, 80, 94).

\section{Горький в карикатурах}

«Можно смело сказать, что ни один из писателей не служил так часто сюжетом для карикатур, как Максим Горький», - утверждал в 1903 г. С. Ф. Либрович (Либрович 1903: 7-8). В 1928 г. сотрудники журнала Прожектор так охарактеризовали количество (и заодно качество) сатирических рисунков, посвященных известному литератору: «бесчисленное множество карикатур, шаржей, всевозможных рисунков с самого начала литературной деятельности сопровождает каждый шаг М. Горького. Невозможно собрать эти груды, в огромном большинстве бессмысленных упражнений в остроумии» (Прожектор 1928: 21). Современный исследователь вторит: «иконография Горького громадна, но тем не менее каждый зафиксированный в ней артефакт представляет значительный интерес, поскольку помогает воссоздать личность писателя, а главное, понять его значимость для современников» (Динерштейн 2016: 12). Столь 
необычное внимание карикатуристов объяснялось «необычным путем писателя в литературу, с новизной героев и тем его произведений. Они диссонировали с привычными понятиями о карьере писателя, о его облике и образе жизни» (Кузнецов-Маркичева 2008: 270).

Количество сатирических изображений Горького превышает все традиционные для русского писателя цифры. Только введенными в научный оборот (а значит, используемыми исследователями) являются 48 карикатур в сборнике 1903 г. (Либрович 1903), 229 карикатур в библиографическом исследовании 1934 г. (Балухатый 1934); 307 карикатур в мемуарном труде 1964 г. (Горький и художники 1964); 147 карикатур в каталоге 1969 г. (Горький в изобразительном искусстве 1969); 27 карикатур в томе «Литературного наследства» 1988 г. (Горький и русская журналистика начала XX века 1988) и т.д.

Необходимо уточнить несколько моментов. Во-первых, часть карикатур в описаниях дублируется. Во-вторых, даже при единичном описании сатирического рисунка число известных карикатур на Горького превышает 500 изображений. В-третьих, даже это внушительное число не исчерпывает всех карикатур на Горького. Это подтверждают как советский исследователь, сотрудник ИРЛИ РАН (Пушкинского Дома) Н. И. Желтова: «тема Горький и изобразительное искусство в горьковедении далеко не исчерпана. При этом она остается неразработанной не только в концепционном отношении, но и в фактологическом» (Желтова 1965: 4), так и современный ученый, заместитель директора по научной работе Государственного музея А. М. Горького М. Г. Кутукова: «полного свода карикатур и шаржей на Горького до сих пор нет» (Кутукова 2010: 475). Поэтому ограничим область наших разысканий дореволюционными карикатурами о литературной среде, в дополнение к фотографической и живописной иконографии Горького, освещенной в первой части статьи.

При всей обширности материала эту тему никак нельзя назвать изученной. Помимо экфрасиса и выходных данных карикатур, информации по иконографии Горького почти нет. Работа 1903 г. (репринт 1995 г.) часто просто дублируется полностью или частично; исключениями можно назвать статьи Э. А. Кузнецова, О. Г. Маркичевой, М. Г. Кутуковой (по фондам Государственного музея А. М. Горького) и Е. А. Динерштейна. После организации в 2006 г. выставки «Литературная баня» («А. М. Горький в дружеских шаржах и карикатурах современников») и передвижных выставок по этой же тематике Государственный музей А. М. Горького (Нижний Новгород) планировал создание базы данных дореволюционных шаржей и карикатур на писателя, но задуманная работа не была закончена. Среди многочисленных новых изданий, посвященных Горькому и его 150-летнему юбилею в 2018 г., не было исследований по сатирической графике. 


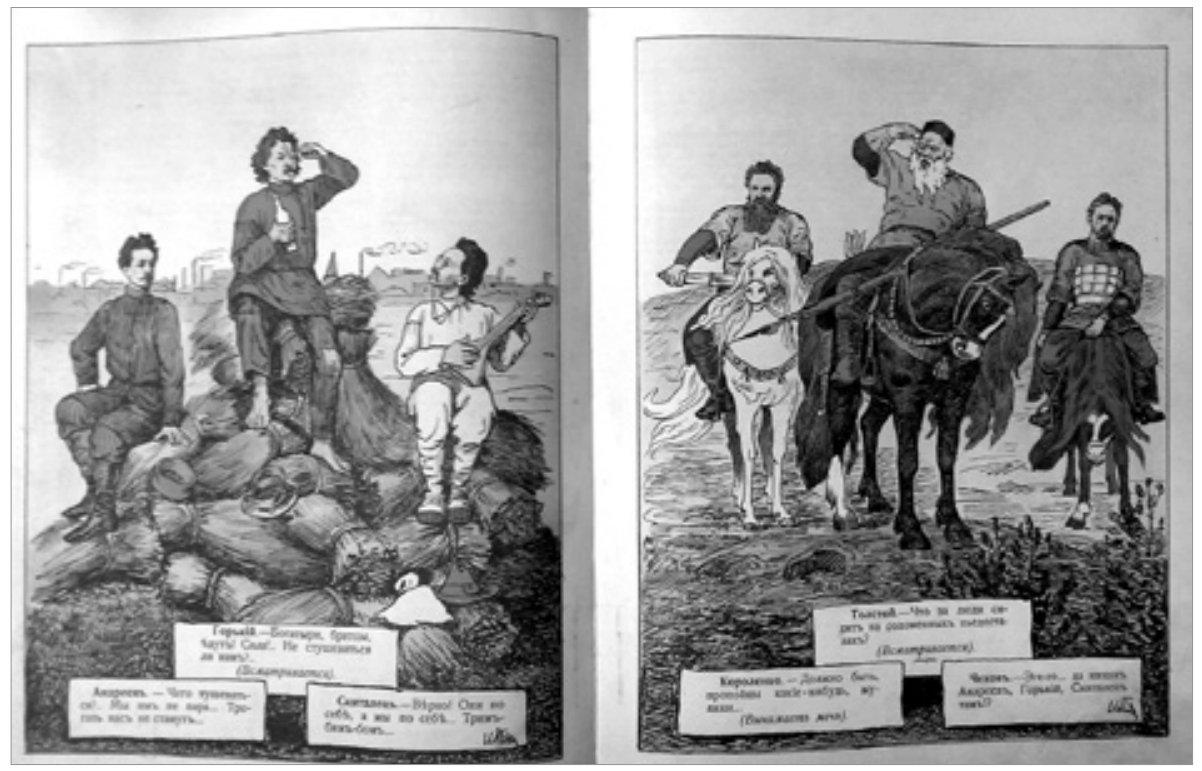

Puc. 4. Шym. 1903. №41. C. 8-9.

Резкий количественный рост сатирической графики на Горького пришелся на начало XX века, примерно с 1901 года (скандал с публикой в МХАТе) и по 1906 г. (отъезд в Америку). Карикатуристы основывались на фотографических изображениях писателя: «бесконечно снимаясь у фотографов во всех возможных и невозможных видах, Максим Горький затрудняется придумать что-либо новое» (Осколки 49 (1902): 2). С точки зрения художника Нашего времени, писатель «выдумывает» это новое, встав на голову перед фотографическим аппаратом (Наме время 49 (1906): 394). В Петербургской газете есть и изображение фотографа, перед которым позирует «неразлучная компания» Горького и его литературного окружения (Либрович 1903: 51). Результаты фотосеансов представлены в виде 15-ти карточек с разными стилями: античным (писатель укутан фиговым листом и увенчан лаврами), египетским (Горький в виде сфинкса), декадентским (руки и ноги Горького поменялись местами и исполняемыми функциями), врубелевским (аллюзия на Демона) и т.д. (Наме время 14 (1903): 114)/ Есть подбор сатирических фотокарточек и, например, с Ф. И. Шаляпиным (Стрекоза 10 (1903): 4).

Важнее представляются изображения писателя в литературной среде. С Л. Н. Толстым Горький предстает то в виде почтительного последователя, то в виде противника графа в борьбе за интеллигенцию (Cтрекоза 35 (1903): 1; Осколки 43 (1905): 1). Противостояние старой и новой литературы обыграно журналом Шут многоцветной аллюзией на картину В. М. Васнецова «Богатыри» (рис. 4), где классические писатели 
(Л. Толстой, Чехов, Короленко) возвышаются на конях, в богатырском облачении, а художники новой формации (Горький, Андреев, Скиталец) сидят на соломенных снопах, сжимая бутылку и балалайку (Шуm 41 (1903): 8-9). Есть и шаржированный отклик на картину Н. Н. Бунина «Рыбная ловля», где изображенные Л. Толстой, Горький, Чехов, И. Е. Репин благодарят С. Любошица, испортившего картину Бунина на выставке Петербургского общества художников: «спасибо вам, а мы и не знали, что у нас такой заступник есть!» (Развлечение 13 (1903): 1). Общественное возмущение картиной, частично оправдывавшее поступок Любошица, объясняется изображением знаменитых писателей без брюк.

Есть оценочные карикатуры с классическим литературным окружением - например, можно припомнить канат популярности, который перетягивают Горький с Чеховым, или весы бессмертия, где труды А. В. Сухово-Кобылина явно тяжелее сочинений Пешкова (Петербургская газета 1903: 3; Шут 10 (1902): 2). Встречаются и относительно бесстрастные - так можно рассмотреть юбилейный шарж на Короленко с журналом «Русское богатство», где чуть поодаль стоят Чехов и Горький (Wym 46 (1903): 2).

Литературные последователи Горького карикатуристами назывались своеобразно: «в газетах, журналах того времени было немало карикатур с подобным названием “подмаксимовики" или “подмаксимки"» (Кутукова - Агафонова 2008: 288). Чаще всего Горький выглядел выше и значительней молодых друзей. Е. Н. Никитин объясняет это так: «Пешкову была присуща такая черта: он хотел, чтобы другие русские литераторы писали так же, как он, только несколько хуже, чтобы оставаться первым. Эту черту, скорее всего, самим писателем до конца не осознанную, подметил и изобразил на своем рисунке художник Н. И. Фидели» (Никитин 2017: 161). Речь идет о карикатуре, где Горький изображен в виде гриба, а у подножия его подрастают Андреев, Бунин и Скиталец (соотношение большой и малых фигур примерно 1:3) (Искры 5 (1903): 34). Утрированное желание известного писателя руководить молодежью (или, наоборот, слепое подражательство новичков) продемонстрировано на рисунке Н. В. Ремизова, где от великана Горького, победно сложившего руки, отбрасывается небольшая тень в виде Андреева, молитвенно тянущегося к образцу (Стрекоза 41 (1905): 4). Об этом же копировании кумира свидетельствует и сатира неизвестного карикатуриста, где Андреев («спутник литературного светила») подглядывает в замочную скважину за читкой Горьким пьесы Дети Солнща артистам Художественного театра, одновременно сочиняя пьесу Дети Луны (Стрекоза 36 (1905): 10). Есть и карикатуры, где прямо показана наставническая роль старшего писателя - например, пастух Горький с подпаском Андреевым (чей рост меньше вдвое) пасут стадо овец, на шерсти которых написано «читатель», травинки же названы произведениями Горького (Шуm 27 (1907): 8-9). О влиянии Горького на Андреева и Скитальца (а также Чехова на Бунина 


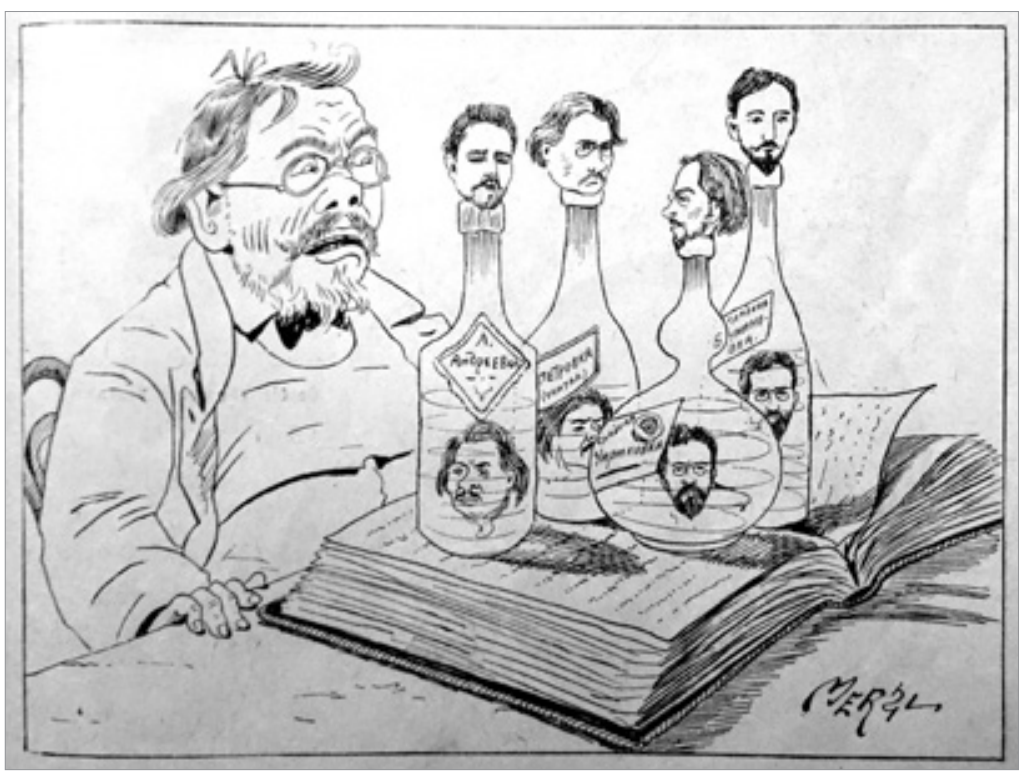

Puc. 5. Наше время. 1903. № 5. 30 янв. С. 33

и Чирикова) говорит карикатура неизвестного художника. Две бутылки спиртного настаиваются на голове Горького и заткнуты фигурными пробками в виде Андреева и Скитальца (другие бутылки повторяют процедуру с остальными авторами) (рис. 5). Потребитель алкоголя - читатель - сетует: горькие и сладкие настойки «на вид “крепко”, а распробуешь — одна вода!» (Наме время 5 (1903): 33).

Неравноценность творчества авторов быстро забывается карикатуристами. Горький, Андреев и Скиталец уже на равных изображены петухами, забрызгивающими грязью публику (Шуm 14 (1903): 8-9), лягушками, живущими в болоте русской литературы (Развлечение 17 (1903): 1), «национальным оркестром литературных сапожников» (Стрекоза 10 (1905): 8-9), беллетристами в простонародной одежде (Стрекоза 18 (1903): 5) или неразумными детьми, дразнящими критика Нового времени (Шут 35 (1904): 4).

Отдельным блоком идут карикатуры, связанные с участием Горького в журналистике. В основном сатириками всячески перепевается тема Новой жизни - газеты, в 1917 г. основанной и издававшейся при его основном участии. Карикатуры на газету позволили художникам продемонстрировать левую политическую линию Горького. Участие писателя в Новой жизни обыгрывается по-разному: то он летописец, который «родину германцам предал» (Пугач 18 (1917): 8); то он Максимка Стырин, назначенный большевиками камергером (Tpenач 6 (1917): 5); то он наездник на Аничковом мосту Петербурга, сам себе воздвигший 
памятник (Бич 36 (1917): 16). Горький прикрывает газетным листом готового к поножовщине большевика, «защищая» его от испуганного прохожего (в подписи к карикатуре - «кровожадного, толстомясого буржуя») (Стрекоза 31 (1917): 1). В диптихе Вечернего времени Горький показан как в прошлом - оборванным писателем, боровшимся с нищетой, так и в настоящем - франтовато одетым, сидящим на мешках с деньгами, но начавшим «"Новую жизнь”, полную борьбы с капиталом» (Вечернее время 1917: 1). Иногда Горького якобы обуревают сомнения в правильности выбранного пути. То он стонет: «я связан по рукам и ногам буржуазной прессой» (Пугач 15 (1917): 5); то недоумевает, как ему теперь удрать в Италию - страну, которую «за семилетний приют мой изругал в “Новой жизни”» (Пугач 12 (1917): 11). И в то же время, покоряясь воле П. И. Пальчинского, за недельное нахождение на посту генерал-губернатора Петербурга закрывшего Новую жизнь, Горький стоически восклицает: «хоть Митькой зови, да газету оставь!» (Бич 38 (1917): 12-13).

Иногда карикатуристы вспоминают об участии Горького и в других изданиях - с журналом Летопись обыгрывается образ летописца Пимена (Рудин 1916: 16). С Летописью, Новой жизнью и газетой Русское слово происходит его чаепитие за тремя самоварами: писатель размышляет, какая «водица скуснее» - пролетарская или буржуазная (Бич 21 (1917): 1).

Совсем немного, в отличие от литературного и журналистского контекста, карикатур, посвященных Горькому, с международным оттенком. Европейский блок насыщен сниженной коннотацией - например, писатель в образе рака ползет к венку «Европейская слава», но цель, судя по сопровождающим крыловским строчкам, недостижима:

Так думает иной затейник,

Что он в подсолнечной гремит,

А он дивит

Свой только муравейник

$$
\text { (Wym } 32 \text { (1907): 13). }
$$

На другом рисунке, выполненном в угрожающе красных тонах, Горький восседает на кипе своих произведений и Новой жизни. В его руках - листок с изображением черепа, скрещенных костей и словом «Программа». Оборванец, один из помощников Горького, готов запалить факел «Социальная революция». Глядя на весь этот ужас, безобидная старушка Европа, в чепце и очках, всхлипывает: «а я-то его, голубчика, по головке гладила, сочинения его читаючи!» (Шym 45 (1905): 1). Карикатуры, посвященные жизни писателя в Америке, чаще всего были связаны с негативным приемом Горького и его гражданской жены М. Ф. Андреевой: например, изгнание невенчанной пары из нью-йоркского отеля (Букет 5 (1906): 9; Петербургская газета 95 (1906): 5). 


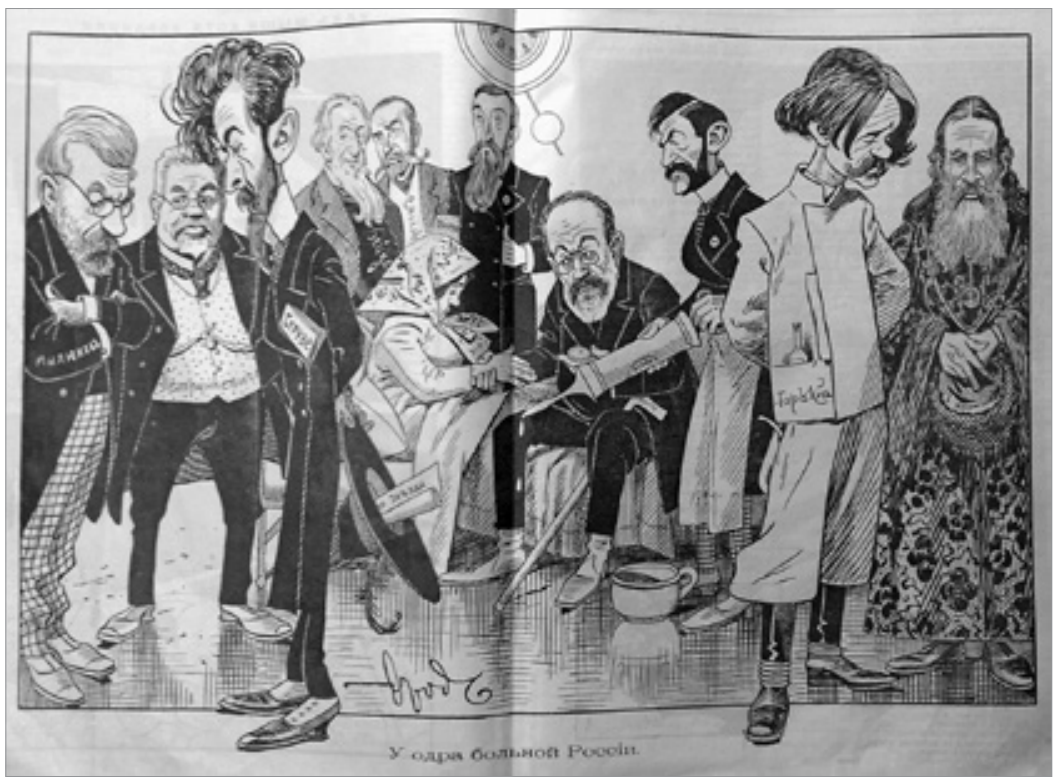

Puc. 6. Стрекоза. 1906. № 1. 14 янв. С. 8-9

Сатирики изображают Горького в зооморфном и растительном виде (Либрович 1903: 7), бесконечно тиражируют его привязанность к босякам (Независимый 1917: 16) и простонародной одежде (Развлечение 33 (1903): 1), утрируют пристрастие к алкоголю (Штрихи и блестки 1903: 1) и «меняют» пол писателя (Наме время 1 (1903): 8), заставляют рыться в мусоре «общественных отбросов» (Будильник 9 (1904): 5). Среди всего многообразия карикатур большая часть довольно безобидна, но особо тревожные визуальные ноты звучат, когда сатирики фиксируют подталкивание Горьким России к революции. Здесь и насильная замена Горьким русского кокошника девицы-России санколютским красным колпаком (Шуm 486 (1905): 2-3), и принесение несчастной связанной страны в человеческую жертву, где Горький наравне с большевиками молится молоху революции (Лукоморье 1917: 6-7). Россия тяжело больна, и знаменитый писатель, похоже, не знает способов ее излечения, печально поникнув главой в окружении многих политических и даже религиозных деятелей той эпохи (Стрекоза 1 (1906): 8-9) (рис. 6).

По многим воспоминаниям, Горький спокойно и даже порой заинтересованно относился к сатире на себя, в целом высоко оценивая этот вид искусства: «а интересная это штуковина - карикатура. Капризная, но нужное искусство, полезное. Оно требует хорошо видеть и тонко изображать смешное» (Горький и художники 1964: 155).

Иконографический каталог Горького, очевидно, никогда не будет собран полностью, но хотя бы стремиться к его всеохватности иссле- 
дователям необходимо - ради уточнения исторического контекста, раскрытия неизвестных до сих пор деталей жизни писателя и его литературного окружения, а также нашего понимания массовых представлений о Горьком, бытовавших среди современников конца XIX — начала XX века.

\section{ЛИТЕРАТУРА}

А. М. Горький в изобразительном искусстве. 1868-1968. Описание изобразительных материалов музея А. М. Горького. М.: Наука, 1969.

А. М. Горький в портретах, иллюстрациях, документах. 1868-1936: пособие для учителей средней школы. М.: Учпедгиз, 1962.

А. М. Горький и В. Г. Короленко. Переписка. Статьи. Высказывания. М.: Государственное издательство художественной литературы, 1957.

А. М. Горький и его современники: Фотодокументы. Описание. М.: Наследие, 1997.

А. Р. «В. Г. Короленко». Шут XLVI/ 15 нояб. (1903): 2.

«А я-то его, голубчика». Шym XLV/12 нояб. (1905): 1.

Архив А. М. Горького. Том VIII. Переписка А. М. Горького с зарубежными литераторами. М.: Издательство Академии наук СССР, 1960.

Балухатый Сергей. Критика о Горьком. Библиография статей и книг 1893-1932 г2. М.; Л.: ГИХЛ, 1934.

«Беллетристы нового века». Шут XIV/5 апр. (1903): 8-9.

«Богатыри, братцы, едут!» Шуm XLI (1903): 8-9.

«В жертву Интернационалу». Лукоморье XXVIII-XXIX/31 авг. (1917): 6-7.

«Вот я вас, крикунов!» Шут XXXV/28 авг. (1904): 4.

Горький и русская журналистика начала ХХ века: Неизданная переписка/Отв. ред. И. С. Зильберштейн, Н. И. Дикушина. Литературное наследство. Т. 95. М.: Наука, 1988

Горький и художники: воспоминания, переписка, статьи/Сост. и авт. вступ. статьи И. А. Бродский. М.: Искусство, 1964.

Горький Максим. «Лев Толстой». Басинский Павел (сост). Горький М. Книга о русских. М.: ПРОЗАиК, 2014: 319-371.

Горький Максим. «О Гарине-Михайловском». Басинский Павел (сост). Горький М. Книга о русских. М.: ПРОЗАиК, 2014: 470-486.

Де Мишель. «Наброски за неделю». Стрекоза XXXVI/4 сент. (1905): 10.

Дени Виктор. «Знаток». Бич XXI/ июль (1917): 1.

Динерштейн Ефим. «Неизвестный шарж из российской Горьковианы». Про книги III (2016): 12-18.

«Дружелюбная встреча Максима Горького в Америке». Петербургская газета 95 (1906): 5.

Желтова Нинель. М. Горький и изобразительное искусство. По материалам Пушкинского Дома. М.-Л.: Наука, 1965.

«Злобы дня». Осколки XLIX/ 7 дек. (1902): 2.

«K LXXV-летнему юбилею графа Л. Н. Толстого». Стрекоза XXXV/31 авг. (1903): 1. «К портретам Сухово-Кобылина и Максима Горького». Шут X/9 марта (1902): 2.

«Какой горький мед!» Штрихи и блестки VII (1903): 1.

Кока /Фидели Николай/. «Подмаксимовики». Искры V (1903): 34.

«Концертный сезон». Стрекоза X/6 марта (1905): 8-9.

Кузнецов Эдуард, Маркичева Ольга. «Жизнь в насмешках и почитании (Максим Горький в карикатурах и шаржах)». Рябов Олег (сост.) Записки краеведов. Нижний Новгород: изд-во «Книги», 2008: 270-285.

Кутукова Марина, Агафонова Елена. «“В обстоятельствах юмористических...” (А. М. Горький в дружеских шаржах и карикатурах современников)». Рябов Олег (сост). Записки краеведов. Нижний Новгород: изд-во «Книги», 2008: 286-292. 
Кутукова Марина. «А. М. Горький в дружеских шаржах и карикатурах (по материалам экспозиционно-выставочной работы Государственного музея А. М. Горького)». Зайцева Галина (отв. ред.). Максим Горький: взгляд из XXI века. Горьковские чтения 2008 года. Нижний Новгород: изд-во Нижегородского госуниверситета, 2010: $475-478$.

Лебедев А. «Иди под мою защиту». Стрекоза XXXI (1917): 1.

Лебедева Алла. «Однажды девяносто лет назад». Нижегородские новости 09.04.1992: 12. Пэм /Матюнин Павел/. «Тетроra mutantur». Вечернее время 21.06.1917: 1.

Леопардус. «Приключение Горького в Нью-Йорке». Букет V (1906): 9.

Либрович Сигизмунд. М. Горький в карикатурах и анекдотах. СПб.: тип. т-ва М. О. Вольфа, 1903.

«М. Горький в карикатуре». Прожектор 1928. XIII (CXXXI)/ 25 марта (1928): 21.

Максим Горький и Нижний Новгород: вокруг музеев. Нижний Новгород: Деком, 2017.

«Максим Горький после 18 июня». Пугач XII/ июль (1917): 11.

«Между двух огней». Осколки XLIII/22окт. (1905): 1.

«Мечты». Tpenaч VI (1917): 5.

М. Мы. «Панургово стадо». Шуm XXVII (1907): 8-9.

«На Парнасе» Развлечение XXXIII / 23 авг. (1903): 1.

«Не придумаешь, как и сняться!» Наме время XLIX/7 дек. (1906): 394.

Никитин Евгений. Семь жизней Максима Горького. Нижний Новгород: ДЕКОМ, 2017. «Новейшие литературные “залежи”». Будильник IX/7 марта (1904): 5.

«Новые фотографии “модного писателя”». Наше время XIV/3 апр. (1903): 114.

Овод /Лабуц Александр/. «Типы наших беллетристов. Прежде. Теперь». Стрекоза XVIII/4 мая (1903): 5.

Овод /Лабуц Александр/. «У одра больной России». Стрекоза I/ 14 янв. (1906): 8-9.

«Отстань, леший! К сарафану да этакую-то шапку!» Шуm XLVIIIб (1905): 2-3.

«Параллели». Независимый I/3 мая (1917): 16.

«Петербургский маскарад». Наше время I / 1 янв. (1903): 8.

«По поводу картины Бунина». Развлечение ХІІІ/29 марта (1903): 1.

Ре-ми /Ремизов Николай/. «М. Горький и его тень». Стрекоза XLI/ 9 окт. (1905): 4.

Рожон. «Горький на мели». Пугач XV/июль (1917): 5.

Роллан Ромен. Собрание сочинений. Т. 8. Л.: Художественная литература, 1935.

Синус /Симаков Иван/. «Новые ужасы большевизма». Бич XXXVI/ сент. (1917): 16.

Современники А. М. Горького. Фотодокументы. Описание. М.: ИМЛИ РАН, 2002.

«Так думает иной затейник». Шут XXXII (1907): 13.

Топиков А. Д. (Праведников Евгений). «Максим Горький — летописец». Рудин IV/янв. (1916): 16.

Тэдди. «Смерть и просветление». Бич XXXVIII/ окт. (1917): 12-13.

«Чья возьмет? (Горький, Чехов и симпатии публики)». Петербургская газета 20.04.1903: 3 .

«Шаляпин и Максим Горький». Стрекоза Х/9 марта (1903): 4.

Эс-пе /Патараки Сергей/. «Летописец из “Новой жизни”». Пугач XVIII/ авг. (1917): 8.

Я. Г. «Современная литература». Развлечение XVII/ 3 мая (1903): 1.

Mersu. «Современный читатель». Наме время V/30 янв. (1903): 33.

\section{LITERATURE}

A. M. Gorkij v izobrazitelnom iskusstve. 1868-1968. Opisanie izobrazitelnyh materialov muzeya A. M. Gorkogo. M.: Nauka, 1969.

A. M. Gorkij v portretah, illyustraciyah, dokumentah. 1868-1936: posobie dlya uchitelej srednej shkoly. M.: Uchpedgiz, 1962.

A. M. Gorkij i V. G. Korolenko. Perepiska. Stati. Vyskazyvaniya. M.: Gosudarstvennoe izdatelstvo hudozhestvennoj literatury, 1957. 
A. M. Gorkij i ego sovremenniki: Fotodokumenty. Opisanie. M.: Nasledie, 1997.

A. R. «V. G. Korolenko». Shut. XLVI/ 15 noyabr. (1903): 2.

Arhiv A. M. Gorkogo. Tom VIII. Perepiska A. M. Gorkogo s zarubezhnymi literatorami. M.: Izdatelstvo Akademii nauk SSSR, 1960.

«A ya-to ego, golubchika». Shut XLV/12 noyab. (1905): 1.

Baluhatyj Sergej. Kritika o Gorkom. Bibliografiya statej i knig 1893-1932 gg. M.; L.: GIHL, 1934.

«Belletristy novogo veka». Shut XIV/5 apr. (1903): 8-9.

«Bogatyri, bratcy, edut!» Shut XLI (1903): 8-9.

«Chya vozmet? (Gorkij, Chehov i simpatii publiki)». Peterburgskaya gazeta 20.04.1903: 3.

De Mishel. «Nabroski za nedelyu». Strekoza XXXVI/4 sent. (1905): 10.

Deni Viktor. «Znatok». Bich XXI/iyul (1917): 1.

Dinershtejn Efim. «Neizvestnyj sharzh iz rossijskoj Gorkoviany». Pro knigi III (2016): 12-18.

«Druzhelyubnaya vstrecha Maksima Gorkogo v Amerike». Peterburgskaya gazeta 95 (1906): 5.

Es-pe /Pataraki Sergej/. «Letopisec iz "Novoj zhizni”». Pugach XVIII/avg. (1917): 8.

Gorkij i hudozhniki: vospominaniya, perepiska, statji / Sost. i avt. vstup. statji I.A. Brodskij. M.: Iskusstvo, 1964.

Gorkij i russkaya zhurnalistika nachala XX veka: Neizdannaya perepiska / Otv. red. I.S. Zilbershtejn, N.I. Dikushina. Literaturnoe nasledstvo. T. 95. M.: Nauka, 1988.

Gorkij Maksim. «Lev Tolstoj». Basinskij Pavel (sost). Gorkij M. Kniga o russkih. M.: PROZAiK, 2014: 319-371.

Gorkij Maksim. «O Garine-Mihajlovskom». Basinskij Pavel (sost). Gorkij M. Kniga o russkih. M.: PROZAiK, 2014: 470-486.

«K LXXV-letnemu yubileyu grafa L.N. Tolstogo». Strekoza XXXV/31 avg. (1903): 1.

«K portretam Suhovo-Kobylina i Maksima Gorkogo». Shut X/9 marta (1902): 2.

«Kakoj gorkij med!» Shtrihi i blestki VII (1903): 1.

Koka /Fideli Nikolaj/. «Podmaksimoviki». Iskry V (1903): 34.

«Koncertnyj sezon». Strekoza X/6 marta (1905): 8-9.

Kutukova Marina. "A.M. Gorkij v druzheskih sharzhah i karikaturah (po materialam ekspozicionno-vystavochnoj raboty Gosudarstvennogo muzeya A.M. Gorkogo)». Zajceva Galina (otv. red.). Maksim Gorkij: vzglyad iz XXI veka. Gorkovskie chteniya 2008 goda. Nizhnij Novgorod: izd-vo Nizhegorodskogo gosuniversiteta, 2010: 475-478.

Kutukova Marina, Agafonova Elena. “"Vobstoyatelstvah yumoristicheskih...” (A.M. Gorkij v druzheskih sharzhah i karikaturah sovremennikov)». Ryabov Oleg (sost). Zapiski kraevedov. Nizhnij Novgorod: izd-vo «Knigi», 2008: 286-292.

Kuznecov Eduard, Markicheva Olga. "Zhizn v nasmeshkah i pochitanii (Maksim Gorkij v karikaturah i sharzhah)». Ryabov Oleg (sost.) Zapiski kraevedov. Nizhnij Novgorod: izd-vo «Knigi», 2008: 270-285.

Lebedev A. «Idi pod moyu zashitu». Strekoza XXXI (1917): 1.

Lebedeva Alla. «Odnazhdy devyanosto let nazad». Nizhegorodskie novosti 09.04.1992: 12.

Leopardus. «Priklyuchenie Gorkogo v Nyu-Jorke». Buket V (1906): 9.

Librovich Sigizmund. M. Gorkij v karikaturah i anekdotah. SPb.: tip. t-va M.O. Volfa, 1903.

Maksim Gorkij i Nizhnij Novgorod: vokrug muzeev. Nizhnij Novgorod: Dekom, 2017.

«Maksim Gorkij posle 18 iyunya». Pugach XII/iyul (1917): 11.

«Mechty». Trepach VI (1917): 5.

Mersu. «Sovremennyj chitatel». Nashe vremya V/30 yanv. (1903): 33.

«Mezhdu dvuh ognej». Oskolki XLIII/22okt. (1905): 1.

«M. Gorkij v karikature». Prozhektor 1928. XIII (CXXXI)/ 25 marta (1928): 21.

M. My. «Panurgovo stado». Shut XXVII (1907): 8-9.

«Na Parnase» Razvlechenie XXXIII/23 avg. (1903): 1.

«Ne pridumaesh, kak i snyatsya!» Nashe vremya XLIX/7 dek. (1906): 394.

Nikitin Evgenij. Sem zhiznej Maksima Gorkogo. Nizhnij Novgorod: DEKOM, 2017.

«Novejshie literaturnye "zalezhi"». Budilnik IX/7 marta (1904): 5.

«Novye fotografii “modnogo pisatelya”». Nashe vremya XIV/3 apr. (1903): 114. 
«Otstan, leshij! K sarafanu da etakuyu-to shapku!» Shut XLVIIIb (1905): 2-3.

Ovod /Labuc Aleksandr/. «Tipy nashih belletristov. Prezhde. Teper». Strekoza XVIII/4 maya (1903): 5.

Ovod /Labuc Aleksandr/. «U odra bolnoj Rossii». Strekoza I/ 14 yanv. (1906): 8-9.

«Paralleli». Nezavisimyj I/3 maya (1917): 16.

Pem /Matyunin Pavel/. «Tempora mutantur». Vechernee vremya 21.06.1917: 1.

«Peterburgskij maskarad». Nashe vremya I/ 1 yanv. (1903): 8.

«Po povodu kartiny Bunina». Razvlechenie XIII/29 marta (1903): 1.

Re-mi /Remizov Nikolaj/. «M. Gorkij i ego ten». Strekoza XLI/9 okt. (1905): 4.

Rollan Romen. Sobranie sochinenij. T. 8. L.: Hudozhestvennaya literatura, 1935.

Rozhon. «Gorkij na meli». Pugach XV/iyl (1917): 5.

«Shalyapin i Maksim Gorkij». Strekoza X/9 marta (1903): 4.

Sinus /Simakov Ivan/. «Novye uzhasy bolshevizma». Bich XXXVI/sent. (1917): 16.

Sovremenniki A. M. Gorkogo. Fotodokumenty. Opisanie. M.: IMLI RAN, 2002.

«Tak dumaet inoj zatejnik». Shut XXXII (1907): 13.

Teddi. «Smert' i prosvetlenie». Bich XXXVIII/ okt. (1917): 12-13.

Topikov A. D. (Pravednikov Evgenij). «Maksim Gorkij — letopisets». Rudin IV/yanv. (1916): 16.

«Vot ya vas, krikunov!» Shut XXXV/28 avg. (1904): 4.

«V zhertvu Internacionalu». Lukomorje XXVIII-XXIX/31 avg. (1917): 6-7.

Ya. G. «Sovremennaya literatura». Razvlechenie XVII/3 maya (1903): 1.

Zheltova Ninel. M. Gorkij i izobrazitelnoe iskusstvo. Po materialam Pushkinskogo Doma. M.-L.: Nauka, 1965.

«Zloby dnya». Oskolki XLIX/7 dek. (1902): 2.

Јелена Гордејева, Јелена Сонина

\section{МАКСИМ ГОРКИ И ЊЕГОВО КЬИЖЕВНО ОКРУЖЕЊЕ: СТРАНИЦЕ ИКОНОГРАФИЈЕ}

\section{Резиме}

У раду је анализирана фотографска иконографија М. Горког од 1880-их година све до смрти писца. Систематизоване су како професионалне фотографије (које су забележили М. Дмитријев, фото студио К. Фишера, А. Бутон, Џ. Бејн), тако и аматерски снимци (које су начинили С. А. Толстој, Л. и А. Средини и др.). Живописни део иконографије Горког чине слике И. Ј. Репина, Н. Н. Буњина, И. И. Бродског и др. Анализа карикатура, на којима је представљен поисац, директно је повезана с предреволуционарним сатиричним издањима као што су Бич, Будилник, Букет̄, Искре, Морски залив, Парамйарчад, Застиращивач, Цврчак, Блебет̄ало, Скице и варнице, Луда и др. Спорведено истраживање омогућава да се презицирају чињенице везане за рад Горког у журналистици (Самарске

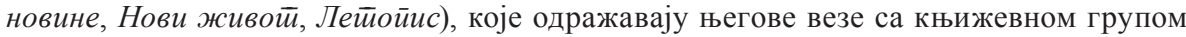
„Средина“, као и стваралачке односе с писцима попут Л. Толстоја, А. Чехова, В. Корољенка, Л. Андрејева. И. Буњина, Скиталца (С. Г. Петрова), Ј. Чирикова, М. Твена, Х. Велса, Р. Ролана и др.

Кључне речи: Максим Горки, иконографија, књижевно окружење. 